\title{
Monteiro Lobato e Samuel Marchak através de seus ilustradores
}

\section{Monteiro Lobato and Samuil Marchak through their illustrators}

Autor: Daniela Mountian Edição: RUS Vol. 11. № 15 Data: Junho 2020 http://www.revistas.usp.br/rus/article/ 


\section{Monteiro Lobato e Samuel Marchak através de seus ilustradores}

\section{Daniela Mountian*}

Resumo: Nos anos 1920, iniciou-se uma revolução global da arte do livro, momento em que começaram a atuar Samuel Marchak (1867-1964) e Monteiro Lobato (1862-1948), duas figuras-chave para o desenvolvimento da moderna literatura infantil de seus respectivos países: Marchak na Rússia, Lobato no Brasil. Além de escritores, ambos foram tradutores e importantes editores, reunindo ao redor de si artistas gráficos e pintores de escolas variadas. 0 artigo apresentará a trajetória de Marchak e Lobato através da análise de algumas capas infanto-juvenis da década de 1920 produzidas para eles por Voltolino (1884-1926), Belmonte (1896-1947), K. Wiese (1877-1974), V. Lébedev (18911967), V. Konachévitch (1888-1963), M. Tsekhanóvski (1889-1965).

\begin{abstract}
In the 1920s began a global revolution in the book art, at this point began to work Samuel Marchak (18671964) and Monteiro Lobato (1862-1948), two key authors for the development of modern children literature in each country: Marchak in Russia and Lobato in Brazil. They were writers, translators and important editors, attracting artists and painters from various schools. The article presents the trajectory of Marshak e Lobato through the analysis of some covers of children books of the 1920s produced for them by Voltolino (1884-1926), Belmonte (1896-1947), K. Wiese (1877-1974), V. Lebedev (18911967), V. Konachevitch (1888-1963), M. Tsekhanovski (1889-1965).
\end{abstract}

Palavras-chave: Monteiro Lobato, Samuel Marchak, design, anos 1920, modernismo, mercado editorial

Keywords: Monteiro Lobato, Samuel Marchak, design, 1920s, modernism, book market 
Quem é que bate à minha porta

Levando uma bolsa tão grossa

E um 5 na placa de cobre, E o quepe azul do uniforme?

É ele,

É ele,

O carteiro de Leningrado!

(..)

$-2-$

- Vem registrada de Rostóv

Para o camarada Jitkóv!

- Uma registrada a Jitkóv?

Não tem ninguém assim, perdão!

- Onde se encontra o cidadão?

- Mas voou ontem para Berlim.

(..)

$-4-$

Lá vem o carteiro alemão Com a última carga na mão. Como um dândi vai assim: Um boné de aba carmim.

(...)

- Carta a Herr Jitkóv agora, De número seis!

- Ontem às onze horas Jitkóv partiu ao país inglês! 
Sob os óculos o porteiro

Repara no nome inteiro

E fala: - Boris Jitkóv!

Para o Brasil se mandou!

$-7-$

\section{$O$ vapor}

Vai partindo

Em poucos momentos

$O$ povo cheio de malas

Ocupa os compartimentos.

Mas a uma dessas cabinas

Malas não são conduzidas.

E lá vai justo quem:

0 carteiro e sua carta.

$-8-$

No Brasil sob as palmeiras,

Do calor vem a canseira,

Sai andando dom Basílio,

$\mathrm{O}$ carteiro brasileiro.

Na mão leva uma carta, Amarrotada e extravagante.

No selo vai uma marca

Da posta de lugar distante.

Sob o nome se vê um lembrete

Dizendo que o destinatário

No Brasil já não está presente

Partiu de volta a Leningrado.

(...)

("O Correio" (A Boris Jitkóv), Samuel Marchak, 1927)

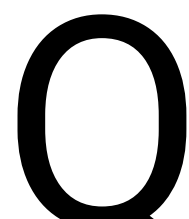

uando o carteiro "mister Smith" foi ${ }^{1}$ procurar Jitkóv e soube que este havia partido para o Brasil, Samuel Marchak (18671964) já havia escrito obras que lhe renderam o epíteto de um dos pioneiros da moderna literatura russa para crianças, como $O$ circo (1925), O sorvete (1925) e A bagagem (1926). Quando o carteiro "dom Basílio" saiu, "sob as palmeiras", para procurar Jitkóv, e soube que este havia voltado para Leningrado, Monteiro Lobato (1862-1948) já havia escrito livros como Narizinho arrebitado (1921) e O marquês de Rabicó (1922), em que aparecem o Sítio do picapau amarelo e as personagens que também renderam ao seu autor o epíteto de pai fundador da moderna literatura brasileira para crianças.

O paralelo proposto faz parte do projeto de pós-doutorado "Literatura infantil russa e brasileira: uma análise comparada (1919-1943)", durante o qual publico uma série de ensaios comparativos, do ponto de vista literário e gráfico, de artistas russos e brasileiros do mesmo período. As leituras são sempre feitas com base em alguns parâmetros (épocas similares, afinidades estéticas, atuações semelhantes, etc.), mas não se trata de estabelecer contatos concretos ou filiações entre essas duas culturas, como preconizavam os primeiros comparatistas franceses. O intuito é, tendo um mesmo problema investigativo, comparar duas semiosferas distintas: "Assim, a investigação de um mesmo problema em diferentes

1 Tradução nossa. 
contextos literários permite que se ampliem os horizontes do conhecimento estético ao mesmo tempo em que, pela análise contrastante, favorece a visão crítica das literaturas nacionais", como pontuou Tania Franco Carvalhal. ${ }^{2}$

Se na Rússia o nome de Marchak costuma constelar com o de Kornei Tchukóvski (1862-1969) na poesia infantil do início dos anos 1920, no Brasil Monteiro Lobato brilha praticamente sozinho na prosa (nessa década, a produção de poesia para crianças era bem menor do que a de prosa).

Como é sabido, Lobato deu nome a uma cidade, sua vida e obra são temas de exposições, em sua homenagem um museu foi construído, pesquisas e livros são no autor inspirados, suas histórias foram traduzidas para diversas línguas, inclusive para o russo - há duas coletâneas soviéticas, até hoje reeditadas: Contos da Tia Nastácia (Skáski Tiótuchki Nastácii), de 1958, com tradução de G. Guilanov, e Ordem do Picapau Amarelo (Orden Joltogo Diátla), ${ }^{3}$ de 1961, com tradução de I. Tyniánova. Esse sucesso se deu devido às aventuras do Sítio do Picapau amarelo, que marcaram gerações de crianças brasileiras, pelo texto em si e por terem sido adaptadas para a televisão mais de uma vez - a primeira delas, na década de 1950, por Tatiana Belinky (1919-2013), brasileira nascida em São Petersburgo, expoente da difusão das letras russas infantis no Brasil. Foram as obras infantis de Monteiro Lobato que fizeram com que a pequena poliglota se apaixonasse pela literatura brasileira (Belinky tinha dez anos quando se mudou com sua mãe para o Brasil) e depois, já adulta, uma profícua escritora para crianças e tradutora, verteu para o português, entre outros, alguns poemas infantis de Samuel Marchak na antologia Di-versos russos (Ed. Scipione, 1992).

\footnotetext{
2 CARVALHAL, 2006, p. 86.

3 Em russo o título foi alterado: em vez de Sítio do Pica-pau amarelo, está Ordem do Pica-Pau-amarelo, provavelmente pelo vocábulo "sítio" ter sido considerado, na URSS, "demasiado burguês", como explicam Marina Darmaros e John Milton. Fazendo o cotejo de Ordem do Pica-Pau amarelo com o original, os pesquisadores analisam as adaptações realizadas na tradução, que evolvem mudanças nas características das personagens (a Emília se torna menos sapeca e teimosa, por exemplo), corte da maioria das referências norte-americanas, e omissão dos elementos de teor racista achados na obra lobatiana. (DARMAROS, 2019).
} 
Tão festejado pelos russos como Lobato o é pelos brasileiros, Samuel Marchak, natural de Vorónej e de origem judia, começou a escrever e a recitar poemas na infância, dividida com cinco irmãos, dois dos quais também se tornaram escritores para os pequenos (M. Ilin e Elena Iliná). Impressionado com os dotes literários de Marchak, o mecenas David Guinsburg (1857-1910), amigo da família, apresenta o menino ao crítico de arte Vladímir Stássov (1824-1906), que "o toma sob sua proteção: cuida da transferência de Marchak para um ginásio petersburguês (os estudos são pagos por F. I. Chaliápin), apresenta-o a M. Górki, fala da criança prodígio a L. Tolstói". ${ }^{4}$ Górki convidou Marchak, por este ter tuberculose, para passar uma temporada com ele em Ialta, e lá o jovem poeta ficou de 1904 a 1906, estreitando laços de uma amizade que nunca se desfez. Desde 1904 começou a publicar textos para leitores adultos, mas foi a literatura infantil que mais tarde lhe deu a possibilidade de conquistar uma posição considerável na sociedade soviética.

Em 1911, envolvido na causa judaica, Samuel Marchak esteve com amigos na Turquia, Grécia, Síria e Palestina, tornando-se correspondente de jornais e revistas. Passou ainda uma temporada na Inglaterra, onde surgiu sua predileção pela literatura inglesa (gosto que compartilhou com Tchukóvski), em especial por William Blake, que chegou a traduzir. Além do ritmo, do nonsense e do humor inglês, Marchak se impressionou com as ideias educacionais teosóficas de Philip Oyler (1880-1973), em cuja escola (Simple Life School) ele trabalhou, em Hampshire e em Wales. ${ }^{5}$ Com um método educacional de vanguarda condizente com os que surgiram na Europa nessa época, Oyler, quase um tolstoiano, ${ }^{6}$ criou um sistema que valorizava a experiência e a autonomia da criança:

Trata-se de um sistema que também dá plena liberdade à criança, que a ensina a não ser preconceituosa, mas tolerante; que não recompensa, nem pune; que não favorece especializações prematuras; que ensina o trabalho doméstico, antes de ensinar a ler e escrever; que educa igualmente os dois sexos; que põe a criança em contato com a natureza; que procura educar pelo exemplo; que valoriza o amor, a religião, a fraternidade entre os povos; que ensina a criança 
a fazer seus próprios brinquedos; que preza a autonomia, a independência do educando. ${ }^{7}$

Ao voltar para a Rússia, durante a Primeira Guerra Mundial, Marchak trabalhou com crianças refugiadas. Em Krasnodar (então Ekaterinodar), ajudara a organizar um centro para crianças sem lar em que havia um teatro infantil. Para esse teatro, em 1920, ele escreveu em parceria com a poeta Elizaveta Dmítrieva (nome de batismo de Tcherubina de Gabriak, 1887-1928) algumas peças que, reunidas dois anos mais tarde, transformaram-se na primeira publicação do poeta voltada para o público infantil.

Também em 1920, Monteiro Lobato escreveu seu primeiro livro para crianças, $A$ menina do narizinho arrebitado. Comparado com seus antecessores, ${ }^{8}$ o autor usa de um estilo menos arcaico e rebuscado, mais ao gosto infantil da época, produzindo textos "de uma invenção original e moderna, escritos em linguagem da mais encantadora vivacidade", ${ }^{9}$ observou Antonio Candido. Fantasia e realidade transitam livremente na composição das diversas personagens que povoam o sítio: o mundo rural, revestido de um nacionalismo irreverente, é o cenário lobatiano por excelência.

Desde que o Brasil se tornou independente de Portugal, em 1822, a definição do que é ser brasileiro, do que o diferencia do português, tornou-se uma questão premente, respondida, na esfera da literatura, pelos românticos, que em geral procuravam seus temas na natureza e na figura do índio, tornada símbolo nacional: "Basta dizer que com a Independência desenvolveu-se cada vez mais a consciência de que a literatura

\footnotetext{
7 BARREIRA, 2014, p. 667.

8 Recentemente, Norma Sandra de Almeida Ferreira, pesquisadora da Unicamp, localizou e estudou um manuscrito do educador João Köpke (1852-1926) intitulado Versos para os pequeninos (1886-1897). Trata-se de poemas de forte oralidade e ritmo contagiante. Embora a obra de Köpke não tenha tido a mesma reperscussão que teve a obra de Monteiro Lobato, Ferreira mostra que, ao integrar à literatura infantil uma linguagem mais coloquial e mais espirituosa, Lobato não estava completamente sozinho. (FERREIRA, 2014) Na Rússia, antes de Tchukóvski e Marchak, também houve experiências literárias que lidaram com o humor e a paródia, não pautadas em motivos puramente didáticos. Valentin Golovin chama a atenção para a revista Gralhinha (Galtchónok) (1911-1913), em especial para os autores S. Gorodiétski e M. Movárskaia. (GOLOVIN, 2014).
}

9 CANDIDO, 1999, p. 67. 
brasileira era ou devia ser diferente da portuguesa (...)" ${ }^{10} \mathrm{Com}$ a abolição da escravatura e a proclamação da república, esse ideal romântico, movido pelos efeitos de uma urbanização acelerada e descuidada, foi de algum modo reavivado e se manifestou em alguns textos da primeira safra de escritores brasileiros que se dedicaram às crianças (fim do século XIX e início do XX), textos marcados, de uma maneira geral, pelo tom didático, patriótico e formal. Lobato não abandona as questões nacionais, mas incorpora a elas o humor, a fantasia e o fantástico, utilizando recursos do conto tradicional, como o antropomorfismo, e criando um diálogo direto com seus jovens leitores. Muitos dos procedimentos explorados por Lobato estão presentes no universo poético de Marchak (humor, antropomorfismo, folclore, etc.), embora eles sejam donos de estilos bastante distintos, escrevam em gêneros diversos (poesia e prosa) e respondam a contextos histórico-sociais específicos. Mas uma coisa é certa: Marchak e Lobato não foram apenas escritores de talento, mas exímios editores.

Em 1922, Marchak retornou de Krasnodar para Petersburgo e começou a dirigir o Estúdio de Literatura Infantil. No ano seguinte passou a editar a revista O Pardal (Vorobei,1923-24), depois renomeada por ele $O$ novo Robinson (para crianças de 8 a 12 anos), na qual colaboraram nomes do calibre de Boris Pasternak (1890-1960), Óssip Maldelstam (1891-1938) e Víktor Chklóvski (1893-1984), além de novos escritores (Vitáli Bianki, Boris Jitkóv, Evguéni Schwartz, M. Ilin). Impressiona o faro infalível do editor Marchak para talentos singulares - como os formidáveis poetas absurdistas-oberiuty Daniil Kharms (19051942) e Aleksandr Vvediénski (1904-1941). Marchak levou muitos escritores da década de 1920 para o mundo infanto-juvenil, e essa capacidade de reuni-los e de estimulá-los foi uma de suas grandes contribuições para a formação de um novo tipo de literatura russa destinada à infância:

Marchak edita obras de escritores novatos (V. Bianki, B. Jitkóv, E. Schwartz, G. Belykh, L. Panteléiev, etc.); uma série de escritores já estabelecidos para "adultos" (M. Zóschenko, D. Kharms, A. Vvediénski, A. Slonímski, V. Kaviérin, N.

10 lbidem, p. 36 
Tíkhonov, etc.), a conselho de Marchak, escreve livros para crianças; além disso, ele atrai para a literatura infantil cientistas que não tinham experiência anterior no trabalho com ela: o classicista S. Lurié (Carta de um jovem grego), o crítico literário Iú. Tyniánov (Kiukhlia), o físico M. Bronstein (Substância solar), e outros."

Samuel Marchak também compreendeu que, para atrair a atenção das crianças, as revistas e os livros, além de didáticos, deveriam ser divertidos e atraentes e esteve ao lado de grandes artistas gráficos. Sua percepção sobre o livro ilustrado reflete o pensamento de editores contemporâneos voltados para o livro enquanto objeto artístico, ou seja, a ilustração não tem a função de explicar o texto, mas de dar novos significados a ele.

Monteiro Lobato também tinha pudores estéticos, mas não menos anseios comerciais: "Chamei desenhistas, mandei pôr cores berrantes nas capas. E também mandei pôr figuras!", disse um dia ele. ${ }^{12}$ A menina do narizinho arrebitado saiu por editora própria, a Monteiro Lobato e Cia. (depois renomeada Cia. Gráfico Editora Monteiro Lobato), fruto da influente Revista do Brasil, que o escritor havia comprado em 1918. O livro teve tão boa recepção entre as crianças que Lobato fez para uma venda ao governo uma edição escolar, de impressão mais barata, com tiragem de 50.500 exemplares (as tiragens comerciais de livros de literatura no Brasil eram bem menores, podendo começar com 1.000 exemplares).

Em 1924, sua editora foi a primeira a importar uma máquina de impressão offset (a Companhia Lithographica Ferreira Pinto, que já tinha o maquinário, trabalhava basicamente com a fábrica de cigarros Souza Cruz). Não é de admirar que a substituição da técnica tipográfica por uma nova (que só será disseminada no país décadas adiante), aliada às oscilações econômicas de um Brasil agrário e conservador, tenha afetado grandemente as finanças da editora, que faliu em 1925, tornando-se, em nova sociedade, a Companhia Editora Nacional, até hoje existente. Eis um exemplo do caráter inquieto e empreendedor de Lobato, que trouxe um novo olhar sobre a indústria do

11 KULECHÓV, 2012, p. 78.

12 HALLEWELL, 2005, p. 326. 
livro, participando de todas as etapas de sua produção, desde a negociação de direitos autorais até a impressão, a distribuição (inaugurou o sistema de consignação) e a propaganda (colocava anúncios em jornal, prática para a qual os outros editores torciam o nariz). Em suma, Monteiro Lobato "revolucionou a feitura do livro":

Antes, este era, ou editado na Europa, ou editado aqui de maneira graficamente incaracterística, por empresas de pequeno porte ou associadas a firmas europeias. Monteiro Lobato concebeu um tipo materialmente original de livro, barato e elegante, destinado a publicar autores brasileiros contemporâneos. A tentativa acabou alguns anos depois no malogro econômico, mas a editora que fundou tornou-se, noutras mãos, uma das mais importantes do Brasil. ${ }^{13}$

$\mathrm{Na}$ época em que Lobato fundou sua editora, a indústria do livro era ainda precária e incipiente. A imprensa só foi implantada no Brasil após a chegada, em 1808, de D. João VI, que, acossado pelas tropas de Napoleão, refugiou-se em sua maior colônia e ali decidiu instalar a primeira gráfica do país (antes disso, qualquer atividade editorial em solo brasileiro era proibida, para evitar insurreições). No entanto, só no século seguinte, a partir da década de 1920, a produção do livro começou a se consolidar, inclusive em matéria de artes gráficas, e Monteiro Lobato teve relevância particular nesse processo.

Nascido em Taubaté, interessou-se por pintura desde pequeno e pensou até em estudar as artes plásticas, mas, desencorajado por seu avô, o Visconde de Tremembé, acabou indo para São Paulo fazer o curso de Direito. Seus dotes de artista, porém, não o abandonaram e ele chegou a colaborar em algumas revistas como desenhista.

Como editor, preocupado em atrair o olhar de seu ledor e entendido no mister, Lobato investiu no seu produto, contratando artistas de talento e produzindo livros amplamente ilustrados, com uma concepção editorial bastante alinhada à produção contemporânea:

Deve-se dizer que a importância de Monteiro Lobato vai muito além dos autores que publicou. $\mathrm{O}$ que realizaram edi-

13 CANDID0, 1999, p. 67 


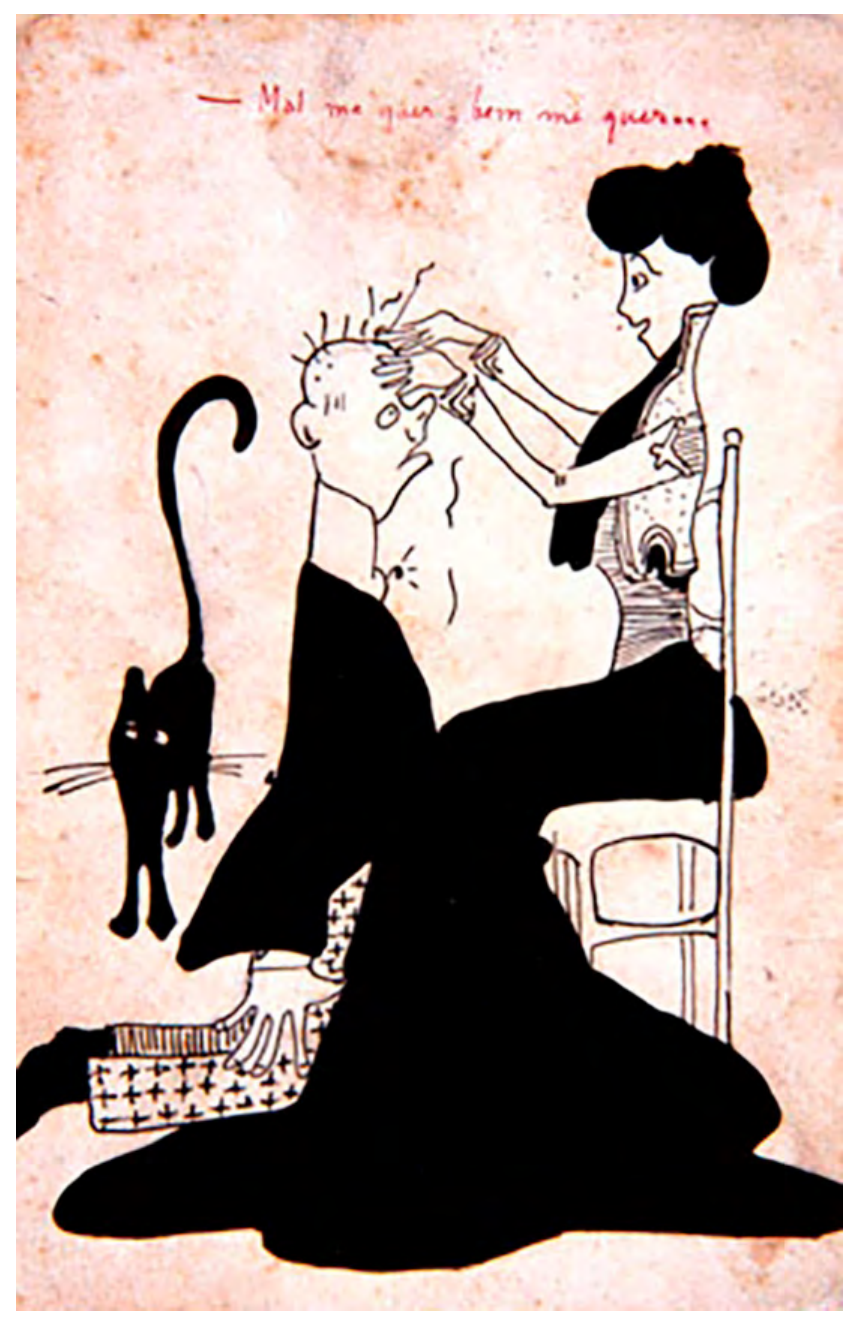

Figura 1: Nanquim de Lobato saturadas. $^{15}$

toras posteriores, como a José Olympio, somente foi possível porque puderam trilhar o caminho que Lobato já havia explorado. Durante os sete anos de sua primeira aventura editorial, ele conseguiu revolucionar todos os aspectos da indústria. (... $)^{14}$

Para dar cara ao seu livro infanto-juvenil de estreia, convidou o paulistano Voltolino, pseudônimo de Lemmo Lemmi (1884-1926). Filho de imigrantes italianos, o caricaturista colaborou em várias publicações brasileiras e ficou conhecido especialmente pelas ilustrações que fez, de 1911 a 1917, para a revista O Pirralho, fundada por Oswald de Andrade. Voltolino era dono de um "traçado ágil, nervoso e despreocupado":

(...) no qual a economia gráfica se destaca. A determinação do risco e rapidez da execução dão organicidade a seus personagens. Voltolino desenha-os primeiro a lápis para depois, já totalmente decidido, finalizá-los com contorno a nanquim. Com relação às cores, gosta de usar as puras e intensas, usualmente trabalhadas em contraste. Salvo quando precisa desenhar em papel couché, em que utiliza a aguada em nanquim e a aquarela, suas cores são

Na capa de A menina de narizinho arrebitado (figura 2) saltam aos olhos o enquadramento e os detalhes decorativos ao redor, quase um arabesco, com linhas sinuosas em estilo art nouveau. Cores fortes contrastantes no traje da menina; elementos de fantasia misturados com os da realidade; e, o mais importante, a criança como figura central da composição (invadindo a moldura). Uma capa desenvolvida para atrair o olhar do leitor ao texto:

A inovadora apresentação gráfica, com capas desenhadas

14 HALLEWELL, 2005, p. 326.

15 VOLTOLINO, 2019. 
Monteiro Lobato e Samuel Marchak através de seus ilustradores

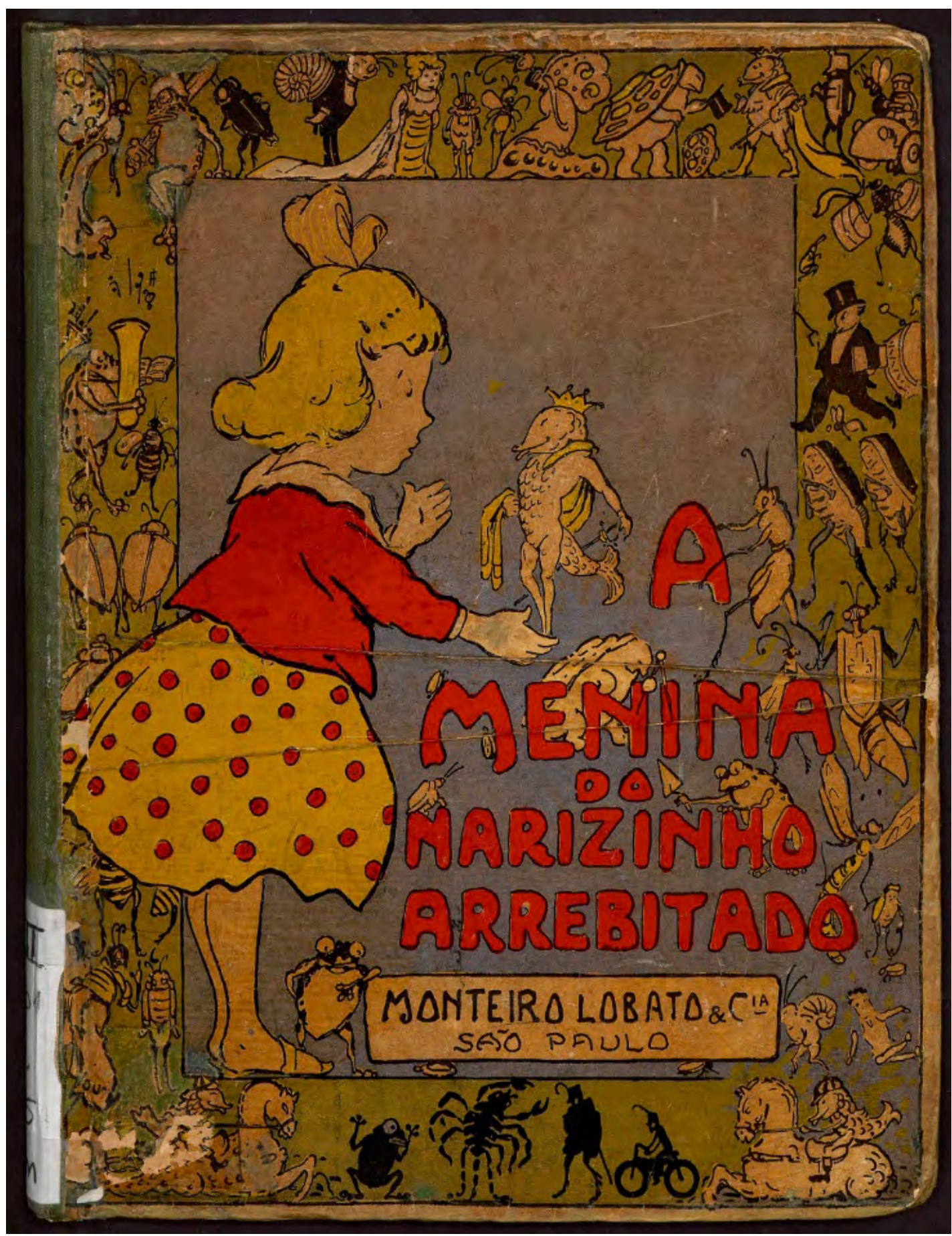

Figura 2: A menina do narizinho arrebitado. Livro de figuras.

Ed. Monteiro Lobato \& Cia. Dezembro de 1920 (1ª edição, São Paulo). Tamanho: 29x22 cm. 
Figura 4: A menina do narizinho arrebitado. Companhia Editora Nacional. 1938 (5ª edição, São Paulo).

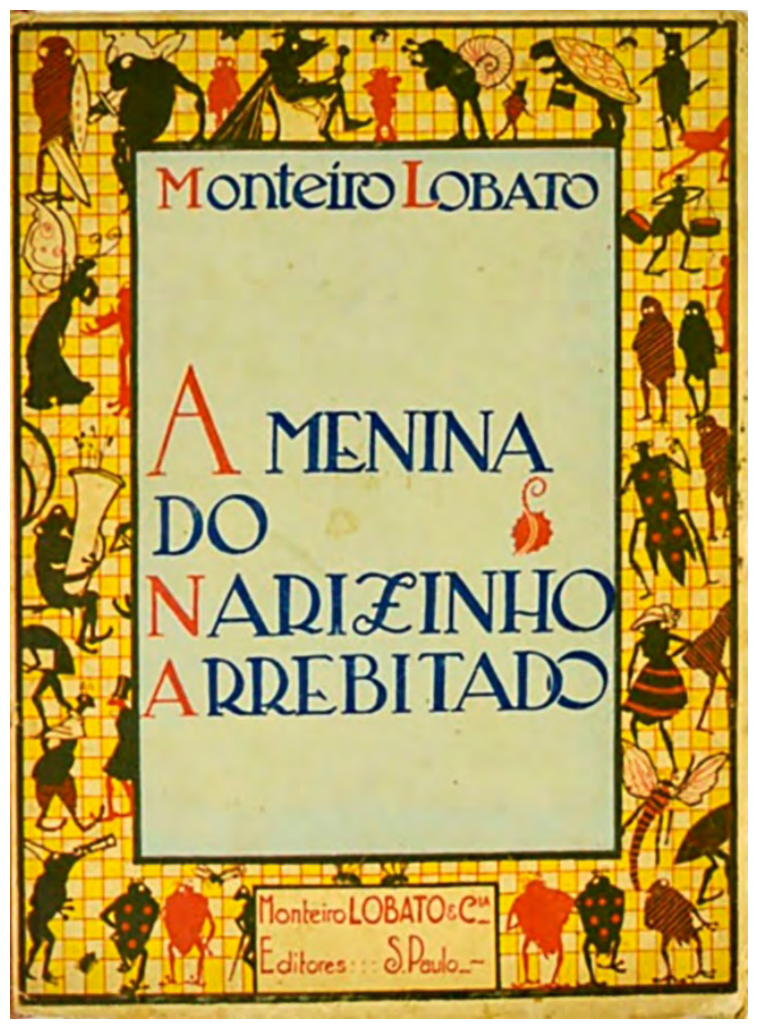

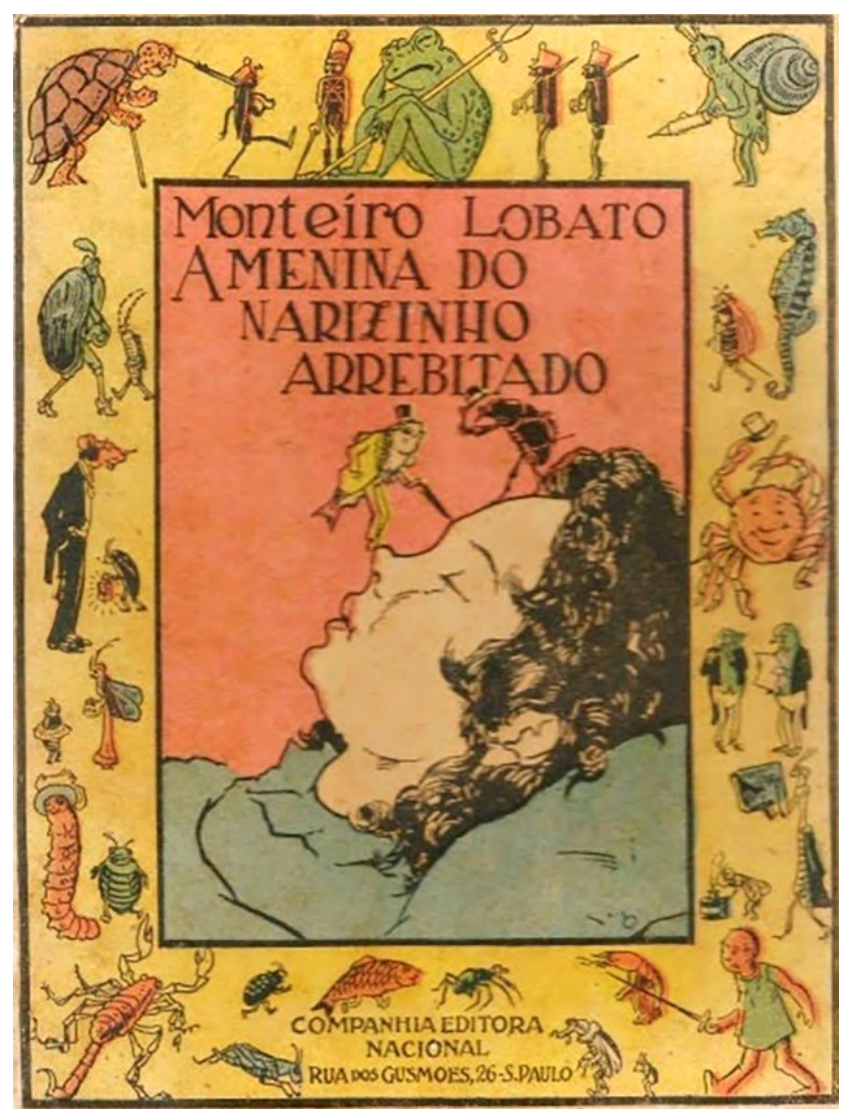

Figura 3: A menina do narizinho arrebitado. Livro de figuras.

Editora Monteiro Lobato \& Cia. $1922\left(2^{\text {a }}\right.$ edição, São Paulo). 
e coloridas para cobrir brochuras, mostrava a preocupação do editor Monteiro Lobato com a embalagem do produto livro, fugindo dos hábitos estabelecidos na época quanto à apresentação de capas, em geral amareladas, copiadas das populares edições francesas. ${ }^{16}$

Nas outras edições (figuras 3 e 4), Voltolino manteve as molduras decoradas de animais, os serezinhos que povoam as aventuras das personagens. A capa da quinta edição traz um close do rosto da menina.

Voltolino ainda assinou a capa de Fábulas (fig. 5), de 1922, em que lançou mão do tradicional recurso da silhueta para dar vida às histórias de Esopo e de La Fontaine que Lobato adaptou à brasileira. Foi o ano da Semana de Arte Moderna - de 11 a 18 de fevereiro o Theatro Municipal de São Paulo foi palco de recitações, exposições e concertos de representantes do modernismo brasileiro, como Anita Malfatti, Oswald de Andrade, Heitor Villa-Lobos e Mário de Andrade, cujo livro Pauliceia Desvairada o editor Lobato recusou-se a publicar. Monteiro Lobato se viu envolvido em vários conflitos com os modernistas, mas certas reivindicações do movimento, pensado em linhas gerais, foram realizadas por meio de sua obra.

Já Marchak, mesmo não sendo um, rodeou-se de vanguardistas e modernistas. Seus primeiros livros dedicados às crianças, assim como os de Tchukóvski (depois da publicação de $O$ crocodilo, de 1917) foram lançados pela editora Ráduga (Arco-íris), uma iniciativa privada criada em 1922 sob a égide da NEP (Nova Política Econômica). Na verdade, ambos os poetas (até hoje um dos mais vendidos na Rússia) estiveram ligados à concepção da editora: eles queriam criar uma nova e moderna revista infantil cujo nome seria Ráduga, o mesmo dado por Górki a uma coletânea que organizara em 1918. No fim, o projeto da revista deu lugar a uma editora, especializada em literatura infantil e dirigida pelo jornalista Lev Kliatchkó (1873-1933). Com participação ativa de Tchukóvski e Marchak, a editora reuniu talentosos escritores, como, por exemplo, Ágnia Bartó (1906-1981), Vitáli Bianki (1894-1959), Boris Jitkóv (1882-1938). A direção artística coube a Nikolai Lápchin (1891-

16 KOSHIYAMA, 1982, p. 70. 

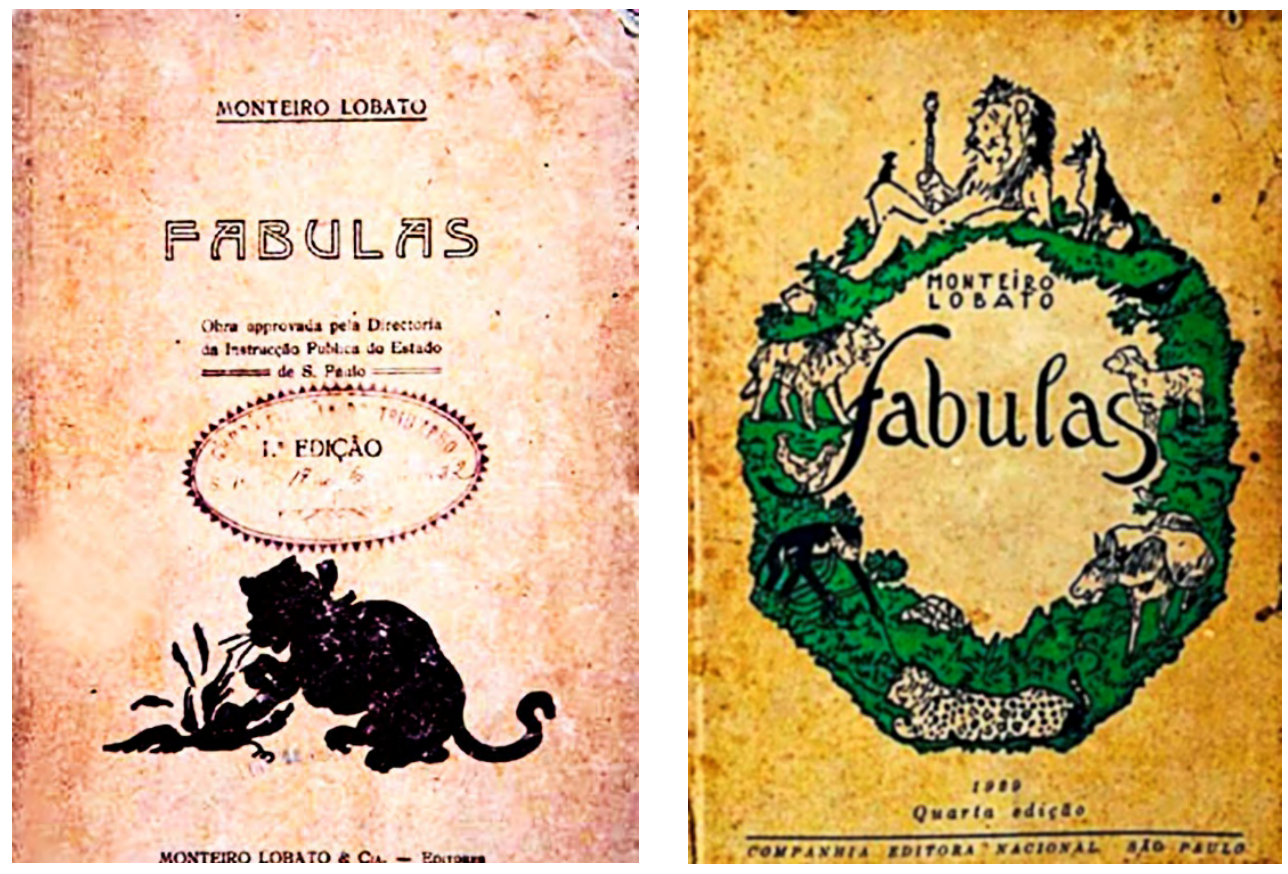

Figura 5: Fábulas.

Monteiro Lobato

e Cia. $1922\left(1^{\text {a }}\right.$

edição, São Paulo).

Capa: Voltolino.

Figura 6: Fábulas. Companhia Editora Nacional. $4^{a}$ edição (1929, São Paulo).

Capa: Voltolino.

1942), "uma das figuras-chave da produção construtivista de livros nos anos 1920". ${ }^{17}$

A Ráduga reuniu duas gerações de artistas modernos: os de vanguarda, como os membros do coletivo "Hoje", e os pintores do grupo "Mundo da Arte" (Mir iskusstva, 1898-1927), como Boris Kustódiev (1878-1927), Mstisláv Dobujínski (1875-1957), Vladímir Konachévitch (1888-1963) e Serguei Tchekhónin (18781936). O coletivo "Hoje", de caráter experimental, foi idealizado por Vera Ermoláieva (1893-1937), um dos nomes decisivos da vanguarda russa, e contou com participação de artistas gráficos de estilos diferentes, como o próprio Lápchin, Ekaterina Túrova (1980?-1953?), Iúri Ánnenkov (1889-1974). A associação durou apenas alguns meses, mas produziu livros formidáveis em linografia sobre textos de S. Iessiénin, A. Kuzmin, A. Riémizov. ${ }^{18}$

A Ráduga, com sede em Petersburgo e em Moscou, funcionou de 1922 a 1930 e lançou cerca de 400 títulos. Não é de hoje que seus livros em litografia são conhecidos fora da Rússia.

17 STEINER, 2019, p. 77.

18 FOMIN, 2015, p. 732. 
Eles foram expostos em vários países e, em 1925, renderam à editora uma medalha da Exposição Internacional de Arte Decorativa em Paris.

Uma das parcerias mais bem-sucedidas e duradouras nascidas na ambiência da Ráduga foi a de Samuel Marchak e Vladímir Lébedev (1891-1967). Quando, em 1924, Marchak tornou-se editor da seção infantil da Gosizdat (acrônimo de Gosudárstvennoie izdátelstvo, Editora Estatal), logo o convidou para ser o diretor artístico. Ambos dirigiram também, a partir de 1933, a sede leningradense da Detguiz (acrônimo de Diétskoie Gosudárstvennoie izdátelstvo, Editora Estatal Infantil).

Vladímir Lébedev ficou conhecido pelos cartazes políticos que produziu no começo dos anos 1920, quando trabalhou numa série criada pela ROSTA (Rossísskoie Telegráfnoie Aguénstvo, Agência Telegráfica da Rússia). A estética arrojada e direta de seus cartazes visivelmente foi aplicada em alguns de seus livros infantis da época (a partir da década de 1930, seus trabalhos ganharam contornos mais realistas). Sua formação em artes ocorreu em estúdios particulares. Entre 1912 e 1914, estudou na escola criada em Petersburgo pelo pintor e artista gráfico Mikhail Bernstein (1875-1960), que também foi professor de outros membros da arte de "esquerda": Nikolai Lápchin (que ilustrou muitos livros de M. Ilin, irmão de Marchak), Vera Ermoláieva e Vladímir Tátlin (1885-1953), e todos ajudaram a levar a produção de livros infantis para outro patamar estético.

As obras de linha construtivista de Marchak-Lébedev, como $O$ sorvete, A bagagem, Ontem e hoje e $O$ circo, tornaram-se um clássico das artes gráficas no momento de sua produção, e trabalhos de muitos artistas da época trazem marcas da escola lebedeviana, como Evguénia Evenbakh (1889-1981), aluna favorita do singular pintor Petróv-Vódkin (ambos foram colaboradores da Ráguga),

Na capa criada por Lébedev para $O$ circo (figura 7), de 1925, admira a simetria construída por meio do palhaço-marionete, trazendo humor e ao mesmo tempo sofisticação à composição 
geométrica, modular e de cores saturadas e contrastantes. 0 nome do poeta e do artista têm o mesmo peso visual, como notou Steiner: "O nome de Lébedev não raro aparecia na capa como coautor" ${ }^{19} \mathrm{e}$, no caso, não poderia ser diferente. Em $A$ arte do livro no contexto da cultura dos anos 1920, Dmítri Fomin chama a atenção para o fato de os desenhos de $O$ circo terem sido feitos antes dos versos, o que não era incomum na época:

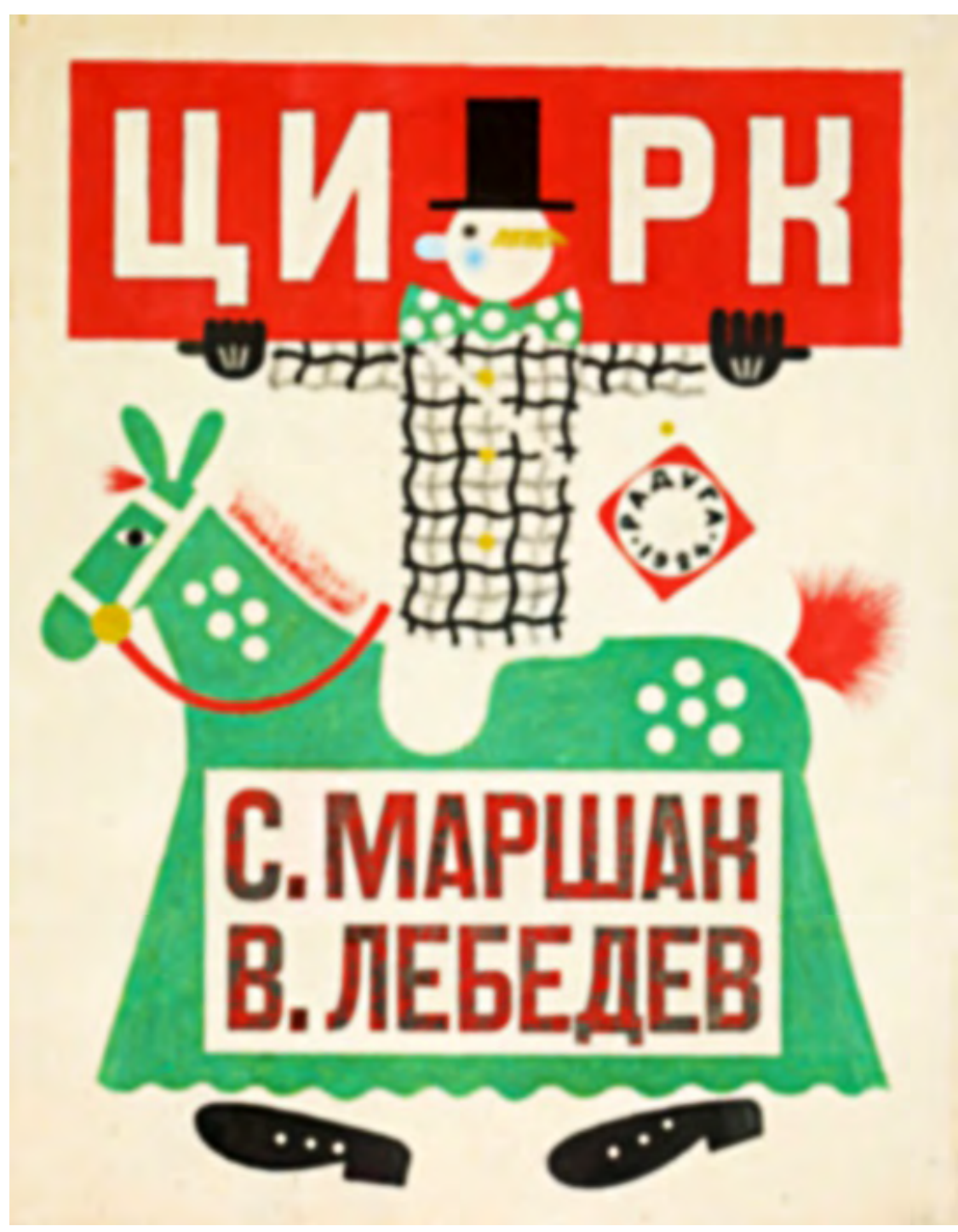

Figura 7. 0 circo. Ráduga. 1

925 (1ª edição). Capa: V. Lébedev.
"Tal método de trabalho era amplamente praticado na Detguiz de Leningrado e produziu muitas obras clássicas da literatura infantil". ${ }^{20}$

Esse processo de criação, além de acentuar o caráter artístico do desenho, explica a síntese ideal entre texto e imagem: a concisão e o humor marchakianos se encaixam perfeitamente no traçado moderno de Lébedev. Fomin também destaca os reflexos da experiência anterior do artista na produção de cartazes: "cada página poderia tornar-se um formidável cartaz". ${ }^{21}$

Na relação que Fomin estabelece entre a produção de livros da década de 1920 e a "arte do espetáculo", O circo de Lébedev constitui caso exemplar: em cada página o leitor/espectador vê um nú-

19STEINER, 2019, p. 322.

20 FOMIN, 2015, p. 218.

21 Ibidem, p. 218. 
Monteiro Lobato e Samuel Marchak através de seus ilustradores

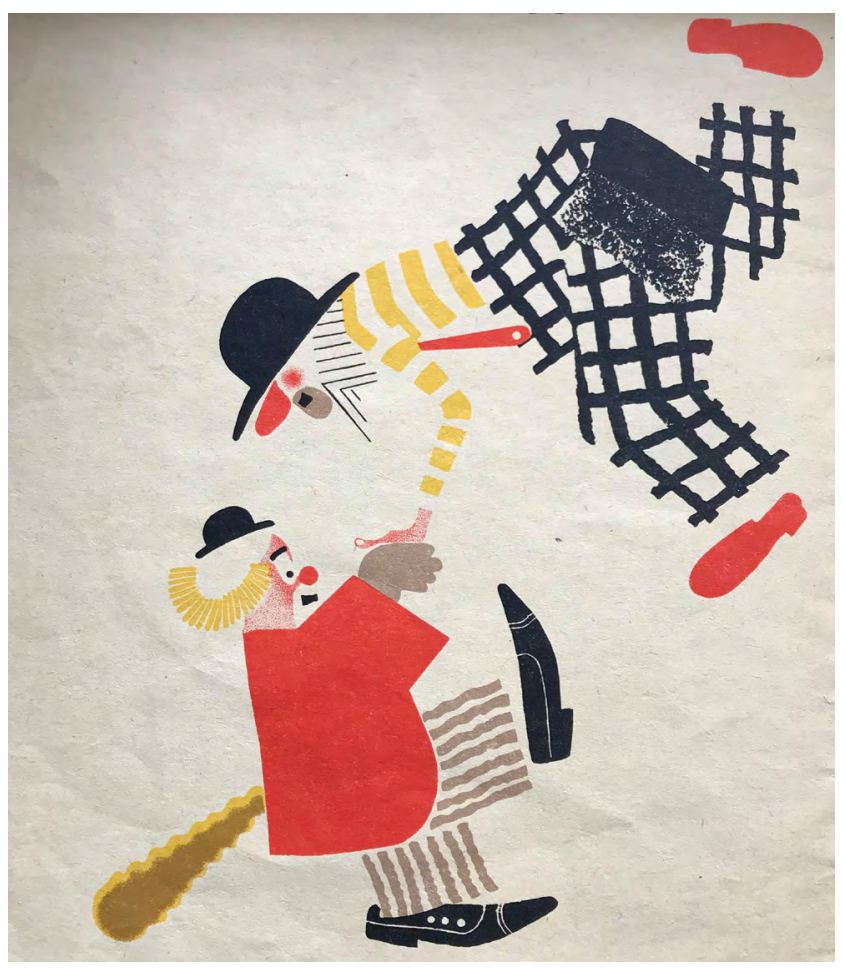

Figura 8. 0 circo. Ilustração: V. Lébedev.

Figura 9. 0 circo. Ilustração: V. Lébedev

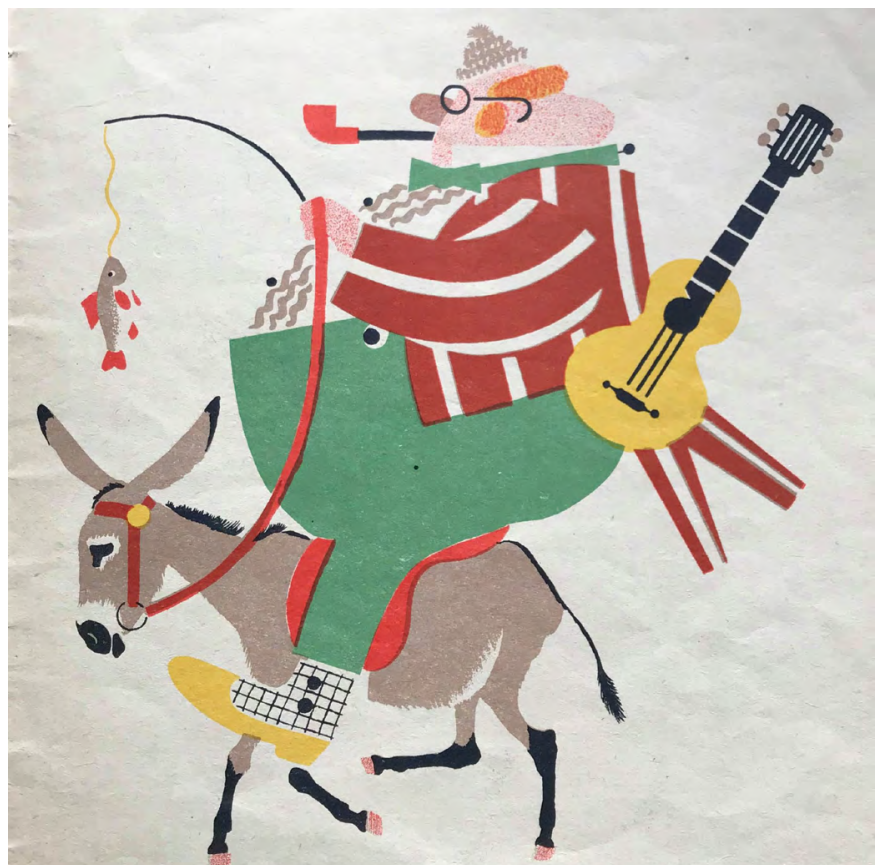


mero circense. Não por acaso Kulechóv (2012), ao analisar a poética de Marchak, usou a expressão "poesia da 'contemplação"' para caracterizar algumas de suas obras. Em todo caso, além de o motivo circense ser tema clássico da arte pictórica moderna, Lébedev morava perto de um circo e o adorava. ${ }^{22}$

O tema circense não poderia faltar ao universo lobatiano. Em 1929, o livro O Circo de Escavalinho é publicado com capa (fig. 10) de Belmonte (1897-1947) - depois o texto foi incluído em Reinações de Narizinho (1931), junto com outras aventuras da turma do Sítio do Picapau Amarelo. Quando O Circo de Escavalinho saiu, Lobato estava nos EUA, pois havia sido nomeado pelo presidente Washington Luís adido comercial do Brasil.

A amizade entre Lobato e Belmonte, apelido de Benedito de Barros Barreto, foi frutífera: cinco títulos em parceria. Além de desenhista e pintor, Belmonte foi jornalista e historiador. Colaborou em várias revistas satíricas e ganhou notoriedade com o Juca Pato, personagem que criou em 1925 para a Folha da Manhã (atual Folha de S. Paulo). Belmonte era adepto assumido de J. Carlos (1884-1950), um dos mais talentosos caricaturistas brasileiros do início do século XX (até Walt Disney tentou levá-lo embora para a América). Se Monteiro Lobato não se identificava com a estética modernista, atraiu para seus livros grandes nomes do jornalismo e da charge política, área em que o Brasil tem larga tradição.

A história de $O$ Circo de Escavalinho descreve as peripécias das crianças do sítio quando resolvem montar um circo. Sintomaticamente, as personagens na capa estão de frente para o leitor/espectador, em cima do tablado. O desenhista tinha apreço pelo detalhe e pelo traço definido e estável: "Os desenhos bem acabados de Belmonte, com sua Narizinho de franjas bem cortadas e um Pedrinho topetudo, ajudaram a popularizar no Brasil o estilo art déco". ${ }^{23}$

A sátira bem-humorada também pode ser encontrada entre as capas de Marchak, como em $O$ nariz torto, livro publicado em 1928 pela Gosizdat com capa (fig. 11) de Vladímir Konaché-

22 Ibidem, p. 220.

23 Catálogo da Exposição "Ilustradores de Lobato: a construção do livro infantil brasileiro (1920-1948)". 12 de outubro a 27 de dezembro de 2015. SESC São José dos Campos. 
Figura 10: 0 circo de Escavalinho. Cia. Editora Nacional.

Capa: Belmonte.

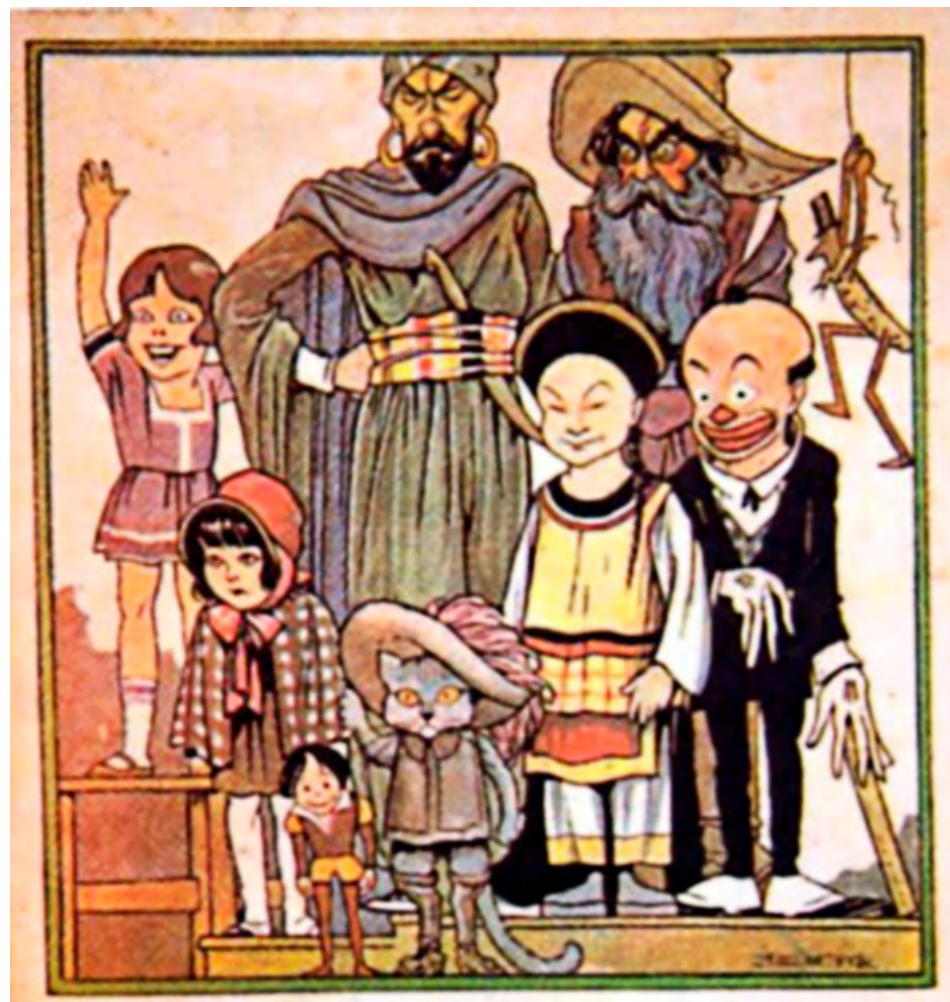

MONTEIRO LOBATO

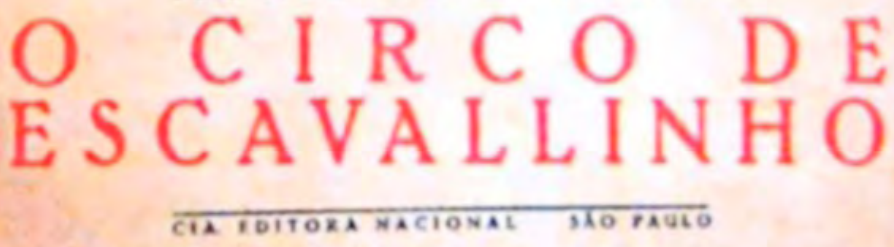

vitch. Os desenhos de Konachévitch são caracterizados por sua "expressividade, a habilidade do pintor em conferir brilho e dramaticidade até a cenas sem importância, transformando todos os elementos representados, sem exceção, mesmo os inanimados, em personagens, dando a cada um deles um traço facilmente reconhecível". ${ }^{24}$ Membro do "Mundo da Arte", Konachévitch passou a se interessar por artes gráficas na década de 1920. Em 1918, teve sua primeira experiência na esfera

24 FOMIN, 2015, p. 452. 


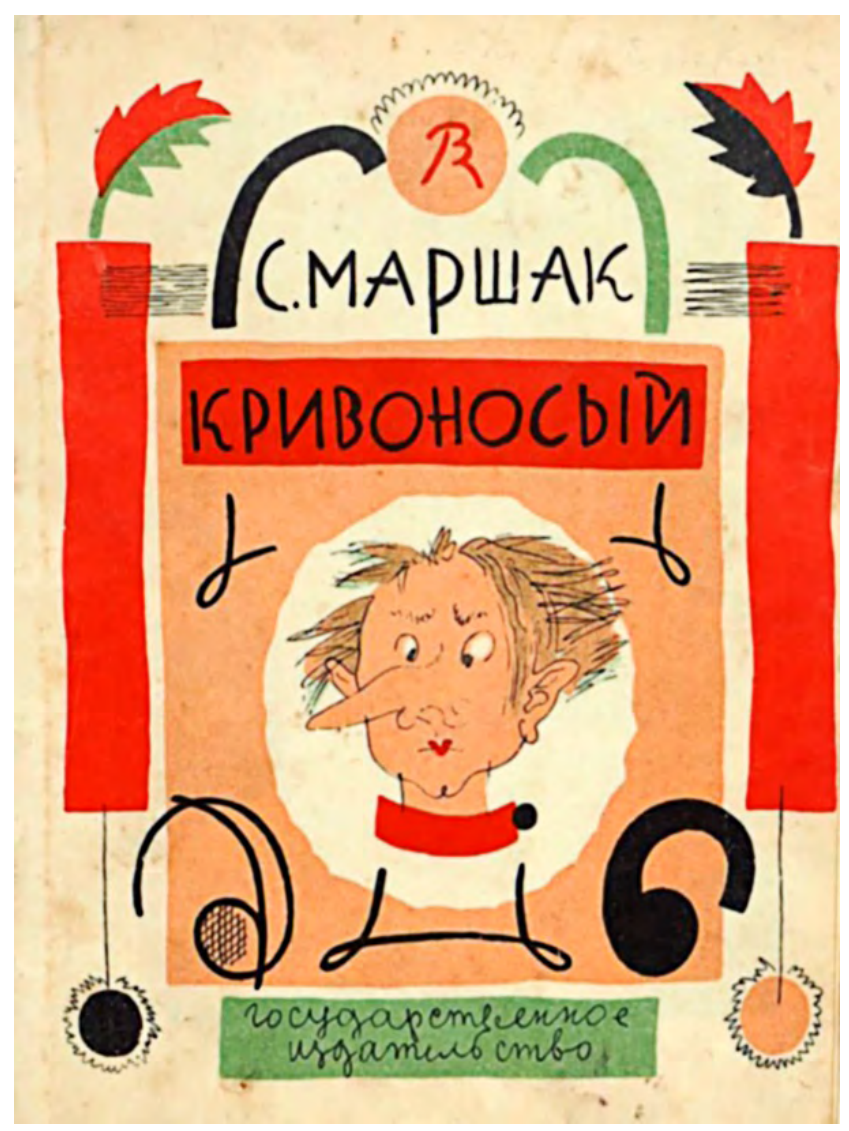

Figura 11: 0 nariz torto. Gosizdat. $1^{\mathrm{a}}$ edição, 1928.

Capa: V. Konachévitch. infantil ao criar o $A b c$ em desenhos, usando a nova ortografia russa adotada em 1917-18.

Konachévitch também assinou as ilustrações e a folha de rosto (fig. 13) de $O$ incêndio (1924), enquanto a capa (fig. 12) foi feita pelo renomado Boris Kustódiev, que se interessou por litografia e linografia e colaborou como caricaturista em algumas revistas. De caráter mais didático, $O$ incêndio revela a preocupação de Marchak com a função edificante das letras infantis.

Mal eclodiu a revolução de 1917, ficou claro que havia necessidade de produzir outra literatura, sem traços do passado, e leitores com outra mentalidade. A educação era a ponta de lança do governo bolchevique: além de uma grande campanha para liquidar o analfabetismo do país (Likbez), criaram-se organizações para jovens (Pequenos outubristas, Pioneiros, Komsomol) e uma literatura para eles praticamente do zero, desde o início condizente com a nova ideologia proletária, mas - enquanto o realismo socialista ainda não tinha se tornado estilo obrigatório - delineada por artistas não raro dotados de uma linguagem arrojada. Na década de 1920, Marchak ainda saiu publicamente em defesa da arte, do skazka e do folclore, indo contra muitos pedagogos e políticos, embora ele nunca tenha negado a importância da função educativa das letras infantis e tenha sido um crítico feroz de escritores do antigo regime considerados "burgueses", como Lídia Tchárskaia (1875-1937), a favorita das jovens do início do século XX, que nos anos 1930 foi condenada ao ostracismo.

Em $O$ incêndio, Samuel Marchak narra um incêndio em que o fogo ganha características humanas. As cenas desenhadas por Konachévitch acompanham o passo acelerado da história e dos jogos de palavras de Marchak: a menina Lena, acossada pelo fogo, é libertada pelo "cavaleiro" Kuzmá, o bombeiro. Com 
um conteúdo mais próximo do realismo socialista (achado em textos de Marchak de meados de 1930), o herói, positivo e sem conflitos, é um homem comum, assim como sua profissão.
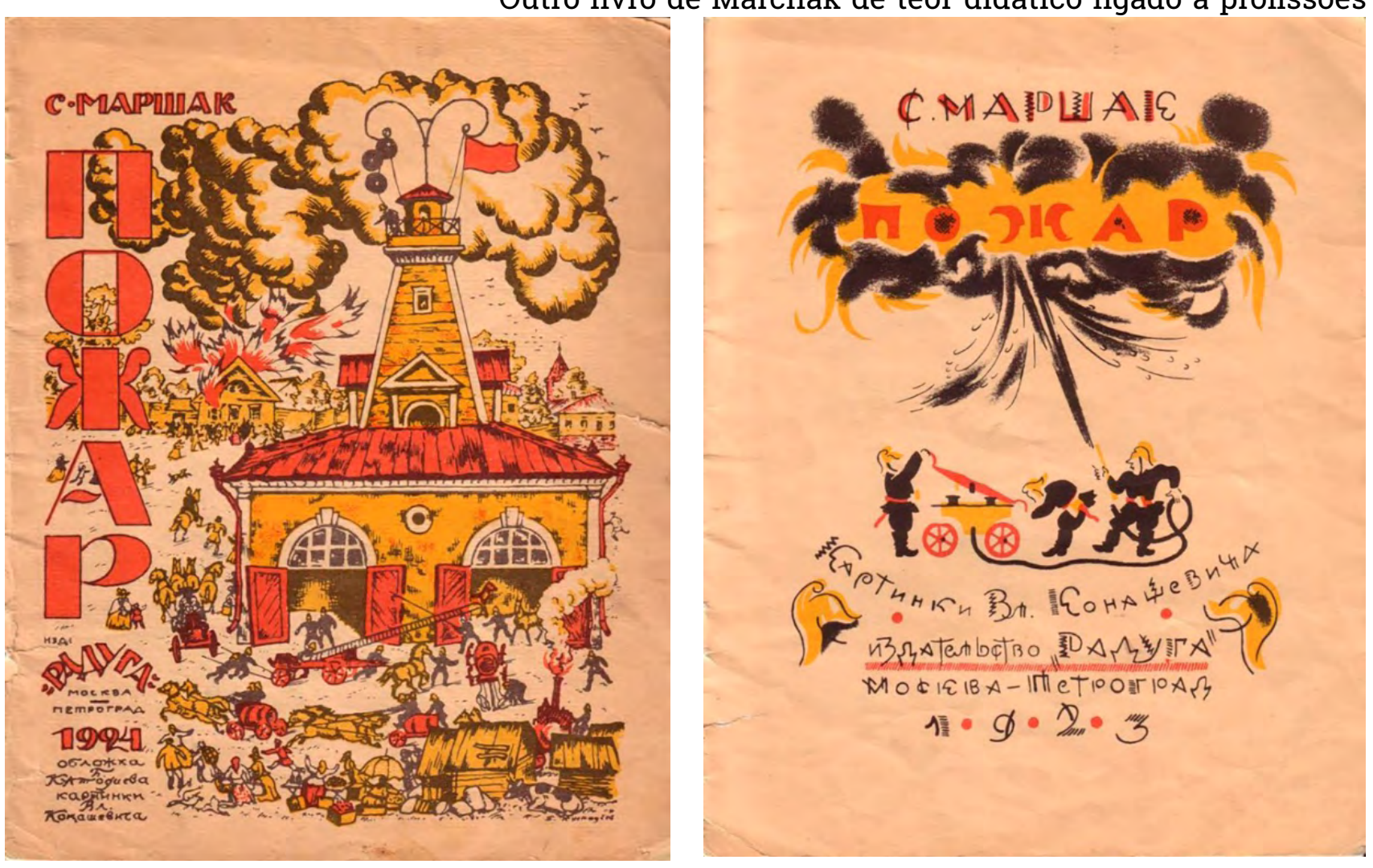

Figura 12: 0 incêndio. Ráduga. $1^{\text {a }}$ edição, 1923. Capa: Kustódiev. Figura 13: 0 incêndio. Folha de rosto: Konachévitch. é $O$ correio (fig. 14), em que, como vimos, carteiros do mundo todo saem em busca do escritor Boris Jitkóv. Entre eles encontramos "dom Basílio" (fig. 15), rodeado de palmeiras e macaquinhos. As imagens estereotípicas relacionadas com o Brasil acentuam o humor dos cenários modernos de Mikhail Tsekhanóvski (1889-1965).

Tsekhanóvski, artista gráfico e diretor de desenhos anima- 


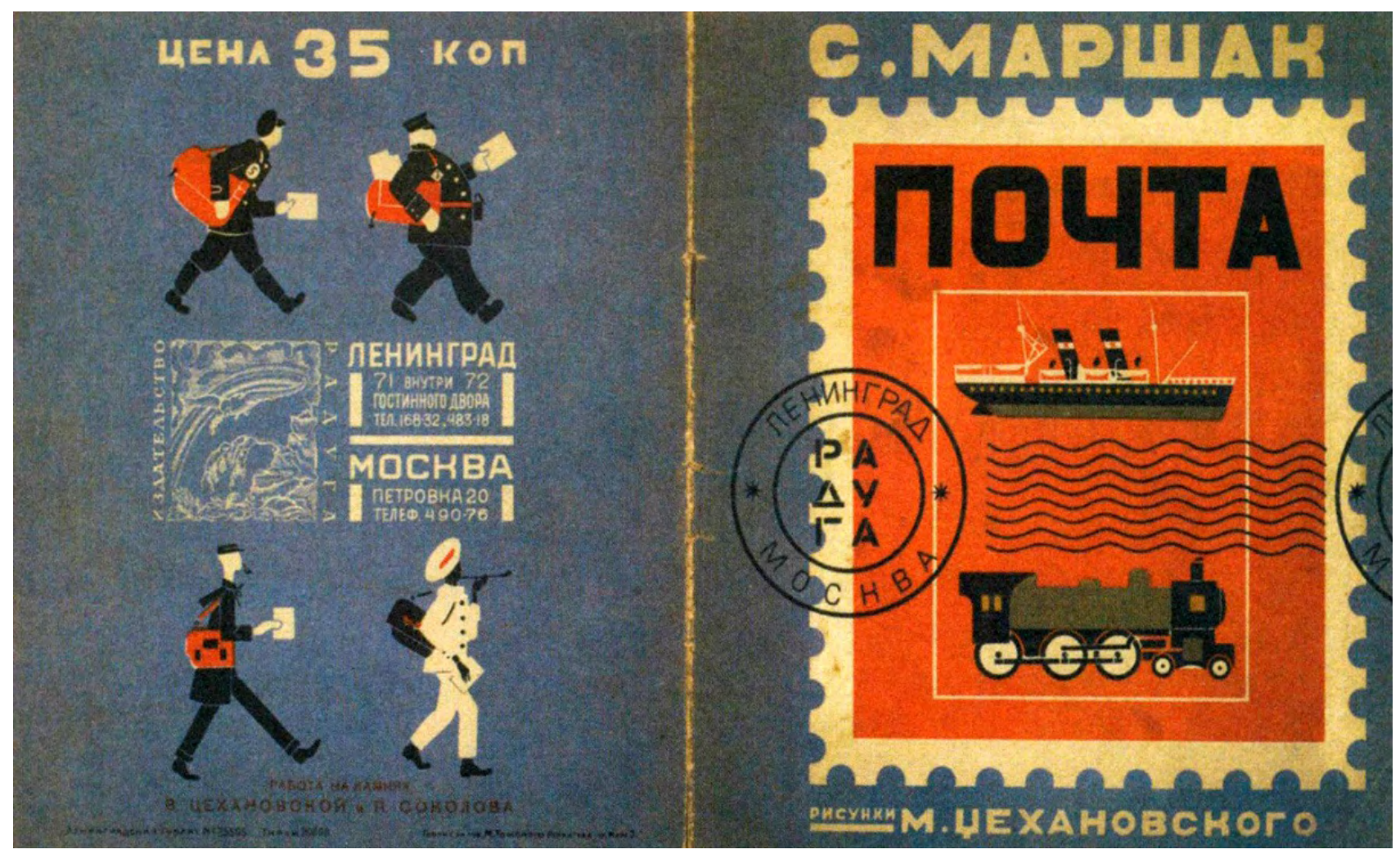

Figura 14: 0 correio. Ráduga. $1^{\mathrm{a}}$ edição, 1925.

Capa: M. Tsekhanóvski. dos, ao lado de Lébedev, é um dos grandes representantes do construtivismo russo nas artes gráficas. Tsekhanóvski fez em 1929 uma animação de $O$ correio baseada nas próprias ilustrações. Em 1933, começou a produzir o que teria sido seu primeiro média-metragem: uma ópera em animação baseada no Conto do pope e seu trabalhador Balda, de Aleksandr Púchkin, com música de Dmítri Chostakóvitch e letra de Aleksandr Vvediénski. Infelizmente, do desenho, que ficara pronto em 1936, só restaram alguns minutos - ele foi destruído num incêndio ocorrido no Lenfilm em 1941, durante a guerra. A partitura também foi perdida.

Monteiro Lobato também se preocupava com a questão educacional, traço que se aprofundou na sua escrita ao longo dos anos 1930, quando o escritor estreitou laços de amizade com o educador baiano Anísio Teixeira (1900-1971). Pai da "Escola Nova", Teixeira, apoiado em ideias de John Dewey (1859-1952), valorizava um ensino democrático, centrado na experiência 


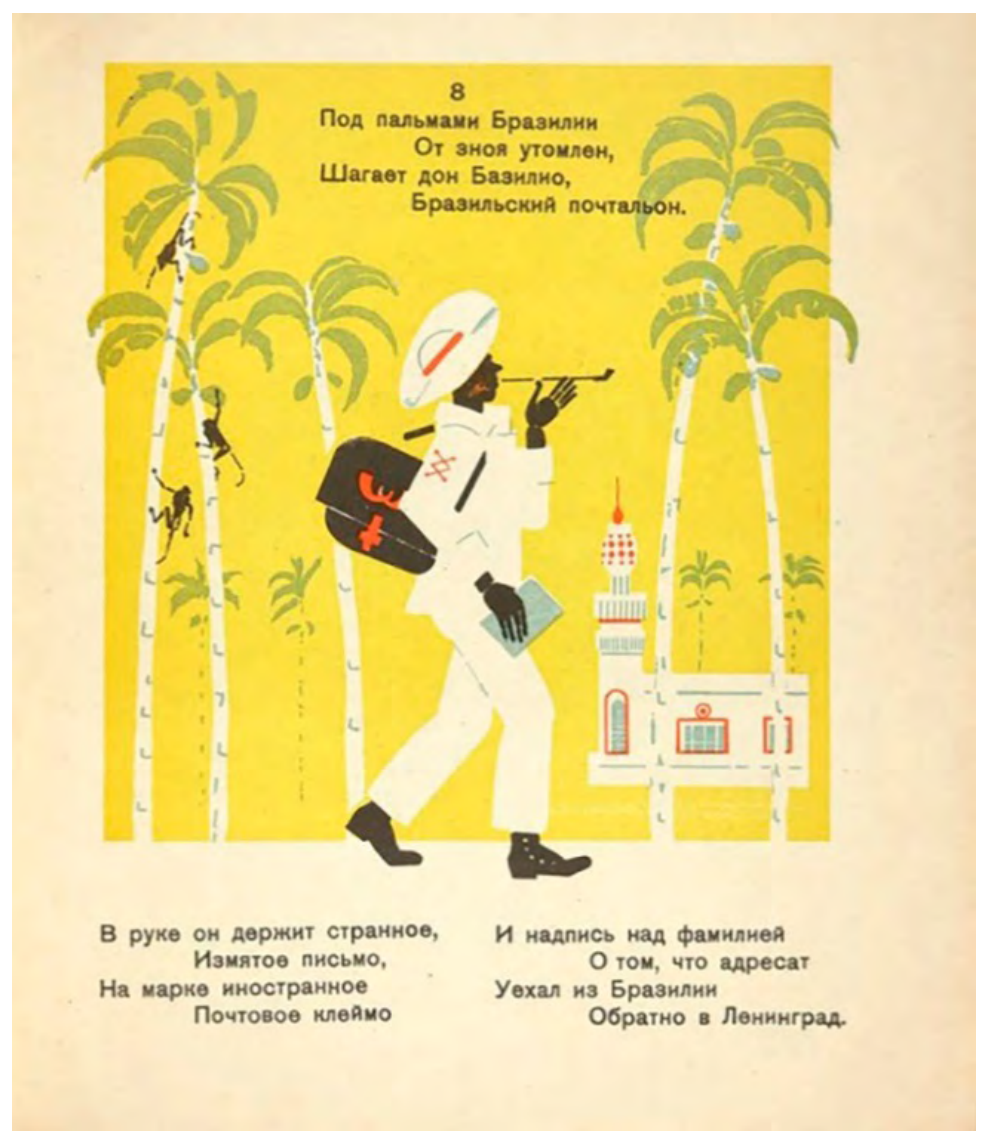

da criança. Exemplos dessa vertente de Lobato são achados, entre outros, em História do mundo para crianças (1933), Geografia de Dona Benta (1935), Aritmética da Emília (1935), Emília no país da gramática (1934). Nesse último, o rinoceronte Quindim leva os amigos do sítio para conhecer o bairro dos adjetivos, o bairro dos arcaísmos, as casinhas dos pronomes, a tribo dos advérbios...

Mas o envolvimento de Lobato em problemas da sociedade brasileira, como se sabe, existiu desde sempre. Um caso notório foi movido pelo livro O escândalo do petróleo (1936), no qual o escritor, admirado com os avanços norte-americanos na área, criticou a atuação do governo de Getúlio Vargas de não explorar o petróleo e de não deixar que o explorassem (o próprio Lobato chegou a montar uma pequena

Figura 15: O correio. Interior. $1^{a}$ edição, 1925. Ilustração: M. Tsekhanóvski. empresa de prospecção de petróleo). Pelas críticas obstinadas, o escritor foi preso por alguns meses em 1941.

Outra campanha que Monteiro Lobato abraçou foi a sanitarista (na Rússia quem o fez foi Maiakóvski). Em 1924, com capa e ilustrações do alemão Kurt Wiese (1887-1974), Lobato publicou Jéca Tatuzinho, que dava às crianças noções de higiene. Jéca Tatuzinho surgiu do Jeca Tatu, personagem que apareceu no primeiro livro de Lobato, Urupês (1918), voltado para o público adulto. A figura de Jeca Tatu simbolizava o caipira indolente, ignorante e letárgico, marcado pelo abandono institucional e pela miséria. A imagem de Jéca Tatuzinho encabeçou campanhas de produtos do Laboratório Fontoura, como o Biotônico Fontoura, cujos cartazes, que correram o Brasil, eram feitos por ilustradores de Lobato, J. U. Campos (1903-1972), Belmonte e Wiese. 
Kurt Wiese teve uma vida aventurosa: viveu seis anos na China e, capturado por japoneses na Primeira Guerra Mundial, ficou cinco anos na Austrália. Mudou-se em 1927 para os EUA, onde fez carreira bem-sucedida, mas antes havia passado uma temporada no Brasil. Foi nessa época que assinou algumas capas de Lobato usando de um traçado ágil e expressivo que dialogava com os quadrinhos.
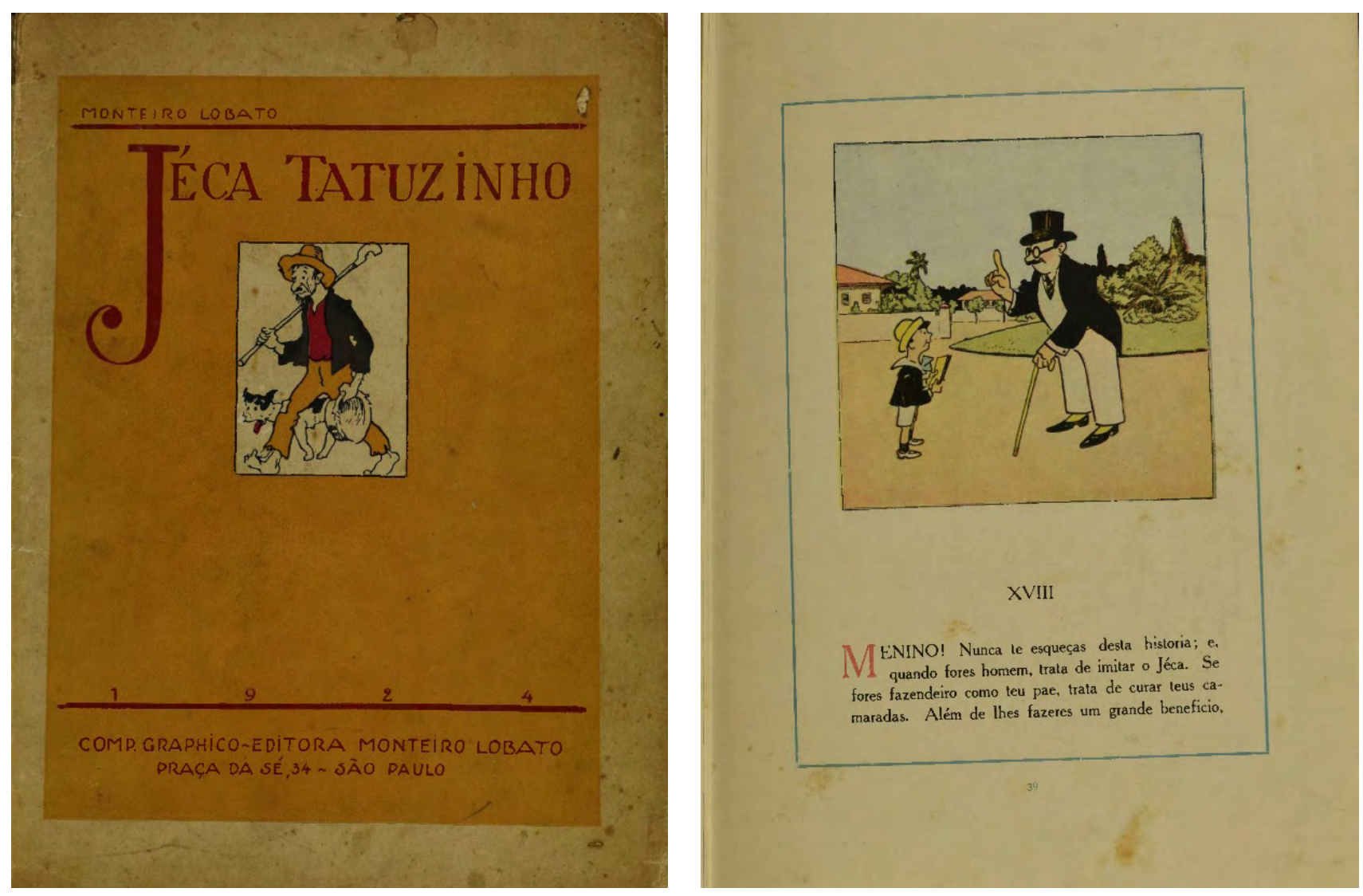

Figura 16. Jéca Tatuzinho. Cia. Gráfico-Editora Monteiro Lobato.

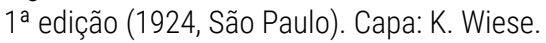

'Figura 17: Jéca Tatuzinho. Ilustração: K. Wiese. 
Os anos 1930 trouxeram mudanças importantes nos dois países (ascensão de Getúlio Vargas no Brasil e consolidação do poder de Ióssif Stálin na Rússia) com desdobramentos nos percursos literários e editorais tanto de Marchak como de Lobato, o que não vem ao caso detalhar neste artigo.

O fato é que, na década de 1920, Monteiro Lobato e Samuel Marchak foram protagonistas da formação de um novo tipo de livro voltado para o público infanto-juvenil. Enquanto escritores, seja na prosa, seja na poesia, ambos buscaram criar uma linguagem mais próxima dos pequenos e acharam nos contos populares tradicionais um arcabouço de procedimentos literários. Enquanto editores, suas atividades foram decisivas para elaborar uma nova feição para as publicações destinadas à infância.

Monteiro Lobato, dono de editora, mudou radicalmente a forma de comercializar e de produzir livros infantis, que se tornaram mais divertidos e mais chamativos, com a presença de ilustradores vindos do jornalismo e, depois, da propaganda. Samuel Marchak ajudou a arregimentar para a produção de livros e revistas infantis ilustradores e pintores das diversas escolas que proliferaram na Rússia no início do século XX - em nenhum país do mundo houve um envolvimento tão intenso de artistas vanguardistas e modernistas em edições infantis como na Rússia. No decorrer da década de 1930 muitos desses artistas (incluindo escritores), que criaram um dos períodos mais impressionantes da literatura russa para crianças, foram banidos (os que conseguiram continuar trabalhando adotaram o realismo socialista, outros emigraram, outros foram mandados para campos de prisioneiros, onde vários perderam a vida). Em todo caso, as obras infantis produzidas por eles, em geral nos anos 1920, tornaram-se um legado inestimável para as artes gráficas, com criações ousadas que, para o deleite de designers, vêm sendo redescobertas e reproduzidas em fac-símile. 


\section{Referências bibliográficas}

BARREIRA, Luiz Carlos. Circulação de modelos sóciopedagógicos: experiências em educação escolar em Portugal no início do século XX. Cadernos da História da Educação, v. 13, n. 2 - jul./dez. 2014.

CANDIDO, Antonio. Iniciação à Literatura Brasileira. São Paulo, Humanitas, 1999.

CARVALHAL, Tania Franco. Literatura comparada. São Paulo: Editora Ática, $4^{\text {a }}$ edição, 2006.

DARMAROS, Marina; MILTON, John. Emília, a cidadã-modelo soviética: Como a obra infantil de Monteiro Lobato foi traduzida na URSS. DELTA, 2019, 35-1.

FERREIRA, Norma Sandra de Almeida. Um estudo sobre "Versos para os pequeninos", manuscrito de João Köpke. Tese de Livre-docência. UNICAMP, São Paulo, 2014.

FOMIN, Dmítri. A arte do livro no contexto da cultura dos anos 1920 (Iskusstvo knígui v kontiekste kultúry 1920-kh godov). Moscou: Rossíiskaia gosudárstvennaia biblioteka, 2015. GOLOVIN, Valentin. Revista Galtchónok (1911-1913) como um experimento literário (Jurnal Galtchónok (1911-1913) kak literatúrnyi eksperimient). Diétskie Tchtiénia, Institut Rússkoi Literatúry (Púchkinskii dom) RAN, tomo $6 \mathrm{n}^{\circ}$ 2, 2014.

HALLEWELL, Laurence. O livro no Brasil. São Paulo: Edusp, 2005.

HELLMAN, Ben. Samuil Marchak: Yesterday and Today. In: BALINA, Mariana; RUDOVA, Larissa. Russian Children's Literature and Culture. Nova York, Londres: Routledge, 2013.

KOSHIYAMA, Alice Mitika. Monteiro Lobato: intelectual, empresário, editor. São Paulo: T. A. Queiroz, 1982.

KULECHÓV, Е. Кулешов. Samuil Marchak. Diétskie Tchtiénia, Institut Rússkoi Literatúry (Púchkinskii dom) RAN, tomo $2 \mathrm{n}^{\circ}$ 2, 2012.

STEINER, Evguéni. O que é bom: ideologia e arte nos primeiros livros soviéticos (Tchto takoie khorocho: ideologuia $i$ 
iskusstvo v rannesoviétskoi diétskoi knigue). Moscou: Nóvoie literatúrnoie obozrienie, 2019.

VOLTOLINO. In: ENCICLOPÉDIA Itaú Cultural de Arte e Cultura Brasileiras. São Paulo: Itaú Cultural, 2019. Disponível em: $<$ http://enciclopedia.itaucultural.org.br/pessoa2488/voltolino>. Acesso em: 06 de Set. 2019. Verbete da Enciclopédia. ISBN: 978-85-7979-060-7

\section{Fonte das ilustrações:}

Fig. 1: monteirolobato.com

Fig. 2-6: capasdelivrosbrasil.blogspot.com

Fig. 7-9: images2.bonhams.com e otvet.imgsmail.ru

Fig.10: capasdelivrosbrasil.blogspot.com

Fig. 11: arch.rgdb.ru

Fig. 12-13: s-marshak.ru

Fig. 14-15: regnum.ru

Fig.16 e 17: digital.bbm.usp.br/handle/bbm/7448

Recebido em: 28/03/2020

Aceito em: 07/04/2020

Publicado em junho de 2020 